\title{
Paprastojo kiečio (Artemisia vulgaris L.) alelopatinis poveikis žieminiams kviečiams ir vasariniams miežiams
}

\author{
Aušra Marcinkevičienè, \\ Edita Eimutytè, \\ Gabrielè Antanavičienè \\ Aleksandro Stulginskio universitetas, \\ Studentu g. 11, \\ LT-53361 Akademija, Kauno $r$. \\ El.paštas: ausra.marcinkeviciene@asu.lt
}

Tyrimai atlikti 2011 ir $2012 \mathrm{~m}$. Aleksandro Stulginskio universiteto Bandymų stotyje. Tyrimų tikslas - nustatyti paprastojo kiečio (Artemisia vulgaris L.) alelopatini poveikị kviečiams ir miežiams. Paprastojo kiečio biomasès (antžeminès dalies ir šaknų) skirtingos koncentracijos vandeninių ištraukų alelopatinè ịtaka žieminių kviečių ir vasarinių miežių grūdų dygimui bei augimui tirta klimatinèje kameroje RUMED 1301 Petri lèkštelèse ant filtrinio popieriaus, sudrèkinto paruoštų koncentracijų vandeninèmis ištraukomis. Eksperimento variantai: 1) distiliuotas vanduo (kontrolinis variantas); 2) 1:6250 (kiečio biomasės ir distiliuoto vandens santykis);3) $1: 1250$;4) $1: 250$;5) $1: 50$;6) $1: 10$.

Atliktais tyrimais nustatyta, kad didžiausias bendras fenolinių junginių kiekis nustatytas paprastojo kiečio lapuose. Kiečio žiedynuose, stiebuose ir šaknyse, palyginti su lapais, fenolinių junginių kaupèsi esmingai mažiau - nuo 19,7 iki $54,4 \%$. Paprastojo kiečio biomasès skirtingų koncentracijų vandeninės ištraukos, palyginti su distiliuotu vandeniu, žieminių kviečių sudygimui esminès įtakos neturëjo, o vasarinių miežių sudygimą esmingai slopino $48,1 \%$ stipriausios koncentracijos (1:10) vandeniné ištrauka. Žieminių kviečių daigų (nuo 23,5 iki 48,0 \%) ir šaknų (nuo 18,5 iki 55,0 \%) augimas, palyginti su distiliuotu vandeniu, buvo slopinamas veikiant paprastojo kiečio $1: 250,1: 50$ ir $1: 10$ koncentraciju vandeninėmis ištraukomis, o miežių daigų (nuo 12,2 iki 43,9\%) ir šaknų (48,8 \%) augimas - veikiant $1: 50$ ir $1: 10$ koncentracijų vandeninemis ištraukomis.

Raktažodžiai: paprastasis kietis, bendras fenolinių junginių kiekis, alelopatinis poveikis

\section{IVADAS}

Didejjantis poreikis saugoti aplinką, susirūpinimas dèl herbicidų poveikio, piktžolių rezistentiškumo vystymasis skatina ieškoti racionalios, ekonomiškos ir tausojančios aplinką piktžolètumo kontrolès strategijos. Kuriant tokią strategiją reikia ivertinti žemès ūkio augalų ir piktžolių biologines ypatybes, dygimo laiką, rūšinę sudètị ir daugelị dirvožemio bei aplinkos veiksnių. Ypač svarbu ištirti žemès ūkio augalų ir piktžolių santykị agrofitocenozèje (Auškalnienè, 2006). Piktžolių paplitimą lemia ịvairūs veiksniai: gamtinès sąlygos (klimatas ir dirvožemio savybès), žmogaus ūkinè veikla (au- ginami žemès ūkio pasèliai, sẻklų valymas, tręšimas, herbicidų naudojimas, rūgščių dirvožemių kalkinimas ir kt.) (Špokienè, Povilionienè, 2003). V. Rašomavičiaus (2008) duomenimis, pastaraisiais metais žemès ūkio pasèliuose ypač padaugejo paprastojo kiečio (Artemisia vulgaris L.), pagal kurị galima spręsti apie apleistų laukų ir dykviečių artimą kaimynystę. Paprastasis kietis - tai daugiametis žolinis, $60-120 \mathrm{~cm}$ aukščio augalas, priklausantis astrinių (Asteraceae) šeimai (Čiuberkis, Vilkonis, 2013). Pasaulyje auga apie 400 Artemisia genties rūšių. Jos paplitusios Šiaurès pusrutulyje, šalto ir vidutinio klimato juostoje. Paprastasis kietis prisitaikęs prie plataus klimatinių sąlygų spektro: ji 
galima aptikti ir aukštų kalnų regione $(3700 \mathrm{~m})$ Šiauriniuose Himalajuose, ir Pietų Amerikos aukštos temperatūros regionuose (Holm et al., 1997). Auga ìvairios granuliometrinès sudèties ir $\mathrm{pH}$ dirvožemiuose - nuo priesmèlio, smèlio iki molio dirvožemių, kurių pH 5,5-6,8 (Barney, DiTommaso, 2003). Vienas augalas subrandina 50-700 tūkst. sèklų (Korsmo et al., 1981), bet kitų autorių duomenimis, labai gerai išsivystę pavieniai kiečiai gali subrandinti net iki $2 \mathrm{mln}$. sèklų (Baleliūnas, 1999). Sèklų minimali dygimo temperatūra $+2-4{ }^{\circ} \mathrm{C}$, optimali $+22-24{ }^{\circ} \mathrm{C}$. Gerai dygsta $0-0,5 \mathrm{~cm}$ sluoksnyje esančios sèklos. Maksimalus dygimo gylis $2-3 \mathrm{~cm}$. Iš sudygusios sèklos rudeni išsivysto skrotelè, o šaknis skverbiasi gilyn ị žemę. Kitais metais išauga žiedinès atžalos (Špokienė, Povilionienè, 2003). Kiečių šaknų diametras yra nuo kelių $\mathrm{mm}$ iki daugiau negu $1 \mathrm{~cm}$, jos gali būti 7-18 cm ilgio (Barney, DiTommaso, 2003).

Piktžolès pasižymi alelopatinėmis savybėmis (Weston, Duke, 2003), savo fiziologiškai aktyviomis išskyromis dažnai gali žemès ūkio augalams trukdyti dygti ir net augti. Apie $30 \%$ augalų rūšių, dažniausiai piktžolès, išskiria it aplinką fiziologiškai aktyvias medžiagas, kurios savo sèklomis, antžemine dalimi ir šaknimis gali paveikti žemès ūkio augalų dygimą ir augimą (Grodzinskiy, 1965). Alelopatija apima abi augalų sąveikas - skatinančią, stimuliuojančią bei slopinančią, inhibitorinę dèl išskiriamų biologiškai aktyvių junginių, kurie vadinami alelojunginiais arba alelochemikalais (Uludag et al., 2006; Al-Watban, Salama, 2012). Manoma, kad paprastojo kiečio biomasès toksiškumas, nustatytas eksperimentuose, priklauso nuo tarpusavyje sąveikaujančių fitotoksiškų terpenų. Buvo nustatyta terpenų, sudarančių eterinius aliejus, sudètis. Tai monoterpenai: $\alpha$-pinenas, $\beta$-pinenas, limonenas, eukaliptolis (1,8-cineolis), kamporas, $\beta$-mircenas, Santolino trianas, kamfenas (Barney et al., 2005). Petri lèkštelèse buvo tiriama paprastojo kiečio vandeninių ištraukų alelopatinè itaka paprastojo kviečio (Triticum aestivum L.), sorgo (Sorghum vulgare Pers.), paprastojo agurko (Cucumis sativus L.), dirvinio bastučio (Brassica campestris L.) ir valgomojo ridikèlio (Raphanus sativus L.) sèklų daigumui ir augimui bei vystymuisi. Vandeninès ištraukos stipriai slopino tiriamųjų žemès ūkio augalų sèklų dygimo energiją ir daigelių augimą. Dirvinis bastutis ir valgomasis ridikas buvo jautresni paprastojo kiečio alelopatiniam poveikiui negu kitos augalų rūšys. Esant kiečio vandeninès ištraukos $0,0125 \mathrm{~g} \mathrm{ml}^{-1}$ koncentracijai dirvinio bastučio, valgomojo ridikèlio, paprastojo agurko, paprastojo kviečio ir sorgo sudygimas sumažejo atitinkamai 100, 87,3, 69,9, 61,1 ir 52,8 \% (Li et al., 2010). Nustatytas kiečio ištraukų alelopatinis poveikis daugiametei svidrei (Lolium perenne L.) ir virgininei pipirnei (Lepidium virginicum L.). Paprastojo kiečio ištraukos, ypač iš jaunų lapų, turèjo slopinantị poveikị tiriamoms rūšims. Daugiametè svidrè buvo atsparesné kiečio alolepatiniam poveikiui negu virgininè pipirnè (Melkania et al., 1982). Tirta paprastojo kiečio biomasès vandeninès ištraukos alelopatinè itaka paprastojo kviečio (Triticum aestivum L.), gausiažiedès svidrès (Lolium multiflorum L.) ir baltosios garstyčios (Sinapis alba L.) sèklų daigumui ir augimui. Kiečio vandeninè ištrauka neturejo įtakos žieminių kviečių daigumui ir augimui, tačiau slopino gausiažiedès svidrès sẻklų daigumą ir augimą. Taip pat nustatyta, kad kiečio šaknų ir stiebų vandeninè ištrauka turèjo panašų mažesni slopinanti poveikị baltosios garstyčios sẻklų daigumui, daigų aukščiui ir šaknų ilgiui negu lapu ištrauka (Pannacci et al., 2011). A. Al-Watban ir H. M. H. Salama (2012) duomenimis, kiečio stipresnių koncentracijų vandeninès ištraukos slopino daržinès pupelès (Phaseolus vulgaris L.) sèklų dygimą ir pradinị augimą.

Didejantis susidomejjimas alelopatija teikia daugiau žinių apie augalų bendrijas ekosistemose ir siūlo naujų priemonių piktžolių kontrolei žemès ūkio augalų pasèliuose (Delabays et al., 2008).

Tyrimų tikslas - nustatyti paprastojo kiečio alelopatinị poveikị kviečiams ir miežiams.

\section{TYRIMŲ METODAI IR SĄLYGOS}

Paprastojo kiečio biomasès skirtingos koncentracijos vandeninių ištraukų alelopatinè įtaka paprastojo kviečio (Triticum aestivum L.) žieminès formos 'Baltimor' ir paprastojo miežio (Hordeum vulgare L.) vasarinès formos 'Simba' grūdų dygimui bei augimui ant filtrinio popieriaus Petri lèkštelèse tirta 2011 m. ASU Bandymų stoties Dirvožemio ir pasèlių ekologijos laboratorijoje. Eksperimento variantai: 1) distiliuotas vanduo (kontrolinis variantas); 
2) $1: 6250$ (kiečio biomasès ir distiliuoto vandens santykis); 3) $1: 1250$; 4) $1: 250$; 5) $1: 50$; 6) $1: 10$.

Paprastojo kiečio èminiai (antžeminès dalies ir šaknų) žydejjimo tarpsniu paimti sertifikuotame ekologiškame plote. Dirvožemis - karbonatingas giliau glejiškas išplautžemis (IDg4-k) (Calc(ar)i-Endohypogleyic Luvisol) ( $\mathrm{VVg}-n-w-c c)$ (Lietuvos dirvožemiai, 2001). Dirvožemio agrocheminès savybès: $\mathrm{pH}-7,01$, humuso - 1,71\%, judriųjų maisto medžiagų dirvožemyje: $\mathrm{P}_{2} \mathrm{O}_{5}-162,5 \mathrm{mg} \mathrm{kg}^{-1}, \mathrm{~K}_{2} \mathrm{O}-$ 192,0 $\mathrm{mg} \mathrm{kg}^{-1}$, bendrojo azoto - 0,095 \%. Paimti èminiai išdžiovinti ir susmulkinti $3 \mathrm{~mm}$ kapojais. Biomasé distiliuotame vandenyje (biomasès ir vandens santykis $1: 10) 18{ }^{\circ} \mathrm{C}$ temperatūroje laikyta 24 valandas. Iš gautos vandeninès ištraukos praskiedžiant buvo ruoštos kitų koncentracijų vandeninès ištraukos: $1: 6$ 250, $1: 1250$, $1: 250$ ir $1: 50$ (Grodzinskiy, 1965; Lazauskas, 1990). Žieminių kviečių ir vasarinių miežių grūdai (30 vnt.) daiginti keturias paras ant filtrinio popieriaus, sudrèkinto paruoštų koncentracijų vandeninèmis ištraukomis, Petri lèkštelèse, klimatineje kameroje RUMED 1301, $22{ }^{\circ} \mathrm{C}$ temperatūroje ir esant $65 \%$ oro drègniui. Apskaičiuotas sudygusių kviečių ir miežių kiekis procentais, išmatuotas jų daigų aukštis ir šaknų ilgis. Tyrimai atlikti 3 pakartojimais.

Tyrimams atlikti kiekviename pasèlyje dirvožemio grąžtu paimti jungtiniai èminiai iš $0-25 \mathrm{~cm}$ dirvožemio sluoksnio. Dirvožemio $\mathrm{pH}$ nustatytas potenciometriškai $1 \mathrm{n} \mathrm{KCl}$ ištraukoje, humuso kiekis - Tiurino metodu, bendrasis azotas - Kjeldalio metodu, judrusis fosforas $\mathrm{P}_{2} \mathrm{O}_{5}$ ir judrusis kalis $\mathrm{K}_{2} \mathrm{O}$ (mg kg-1 dirvožemio) - Egnerio-Rimo-Domingo (A-L) metodu. Tyrimai atlikti Maisto žaliavų, agronominių ir zootechninių tyrimų laboratorijoje. Dirvožemio vienetas nustatytas pagal naujają Lietuvos dirvožemių klasifikaciją (LTDK-99), suderintą su FAO UNESCO Pasaulio dirvožemių žemèlapio legenda (Lietuvos dirvožemiai, 2001).

Bendras fenolinių junginiu kiekis paprastojo kiečio skirtingose morfologinèse dalyse (žiedynuose, lapuose, stiebuose ir šaknyse) nustatytas spektrofotometriniu Folino metodu (Ragaee et al., 2006). Tyrimai atlikti Maisto žaliavų, agronominių ir zootechninių tyrimų laboratorijoje 3 pakartojimais.

Tyrimų duomenys statistiškai įvertinti pagal $t$ ir Fišerio kriterijus bei mažiausią esminio skirtumo ribą (Raudonius ir kt., 2009). Tyrimų duomenų statistine analizè atlikta naudojantis kompiuterinemis programomis STATENG ir DISVEG.

\section{TYRIMŲ REZULTATAI IR JŲ APTARIMAS}

Bendras fenolinių junginių kiekis skirtingose paprastojo kiečio morfologinèse dalyse. Didžiausias bendras fenolinių junginių kiekis nustatytas paprastojo kiečio lapuose (vidutiniškai $1,93 \mathrm{mg} \mathrm{g}^{-1}$ ) (1 pav.). Kiečio žiedynuose, stiebuose ir šaknyse,

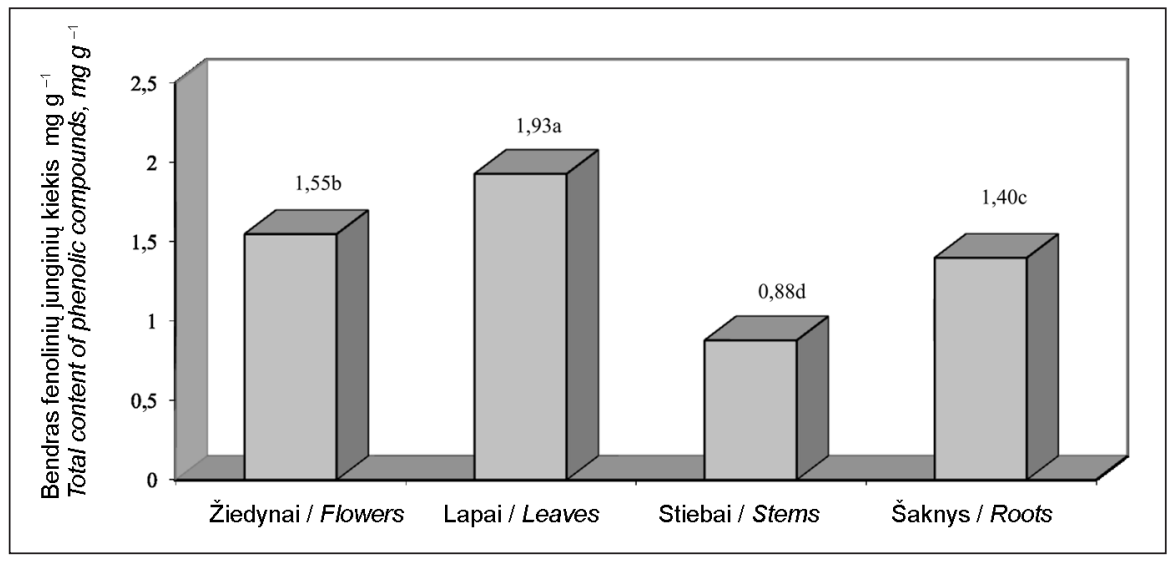

1 pav. Bendras fenolinių junginių kiekis skirtingose paprastojo kiečio morfologinèse dalyse, $2012 \mathrm{~m}$.

Pastaba: tarp variantų vidurkių, pažymètų ne ta pačia raide $(a, b, c, d)$, skirtumai yra esminiai $(\mathrm{P}<0,05)$.

Fig. 1. The total content of phenolic compounds in different morphological parts of common mugwort, 2012

Note: means not sharing a common letter $(a, b, c, d)$ are significantly different $(P<0.05)$ 
palyginti su lapais, fenolinių junginių kaupèsi esmingai mažiau - nuo 19,7 iki 54,4 \%. Kiečio šaknyse fenolinių junginių susikaupè esmingai $59,1 \%$ daugiau negu stiebuose, tačiau esmingai 9,7 \% mažiau negu žiedynuose.

Fenoliniai junginiai, kaip antriniai augalų metabolitai, svarbūs vykstant alelopatinei augalų tarpusavio sąveikai (Xuan et al., 2005). Kiečių sudètyje randama tokių biologiškai aktyvių junginių kaip sterolių, terpenų, flavonoidų, saponinų ir taninų (Al-Watban, Salama, 2012). Tyrimais nustatyta, kad daugiausia alelochemikalų susikaupia augalų lapuose, palyginti su kitomis morfologinèmis dalimis (Gill et al., 2009).

Paprastojo kiečio alelopatinis poveikis skirtingiems žemès ūkio augalams. Ištyrus paprastojo kiečio biomasès skirtingų koncentracijų vandeninių ištraukų ịtaką žieminių kviečių sudygimui, nustatyta, kad visų koncentracijų vandeninèse ištraukose kviečių sudygimas (nuo 85,7 iki $92,3 \%$ ) esmingai nesiskyre (2 pav.). Pastebèta tendencija, kad paprastojo kiečio biomasès $1: 1250$ ir 1 : 250 koncentracijų vandeninèse ištraukose, palyginti su distiliuotu vandeniu, kviečių dygimas buvo labiausiai stimuliuojamas. H. Önen ir Z. Özer (1999) nustatè, kad paprastojo kiečio lapų ir šaknų sausoji masė slopino kviečių grūdų dygimą.

Didžiausias žieminių kviečių daigų aukštis nustatytas juos daiginant distiliuotame vandenyje (3 pav.). Paprastojo kiečio biomasès $1: 250,1: 50$ ir 1 : 10 koncentracijų vandeninèse ištraukose, palyginti su distiliuotu vandeniu, kviečių daigu augimas buvo esmingai slopinamas, atitinkamai nuo 23,5 iki 48,0 \%.

Paprastojo kiečio biomasès silpnesnès koncentracijos (1:6 250, $1: 1250$ ir $1: 250)$ vandeninèse ištraukose kviečių šaknų ilgis esmingai nesiskyrè nuo distiliuoto vandens, o stipresnès koncentracijos (1:50 ir $1: 10)$ vandeninèse ištraukose šaknų ilgis esmingai sumažèjo nuo 18,5 iki 55,0 \%. R. I. Abdel-Fattah ir kt. (2011) duomenimis, stipresnès koncentracijos kiečio vandeninès ištraukos slopino ne tik žieminių kviečių grūdų dygimą, bet ir jų daigų bei šaknų augimą.

Vasariniai miežiai paprastojo kiečio biomasès vandeninių ištraukų poveikiui buvo jautresni negu žieminiai kviečiai (4 pav.). Paprastojo kiečio biomasès vandeninèse ištraukose vasarinių miežių sudygo nuo 41,0 iki 85,3 \%, t. y. vidutiniškai 16,0 \% mažiau negu žieminių kviečių. Esmingai mažiau (48,1 \%) vasarinių miežių, palyginti su

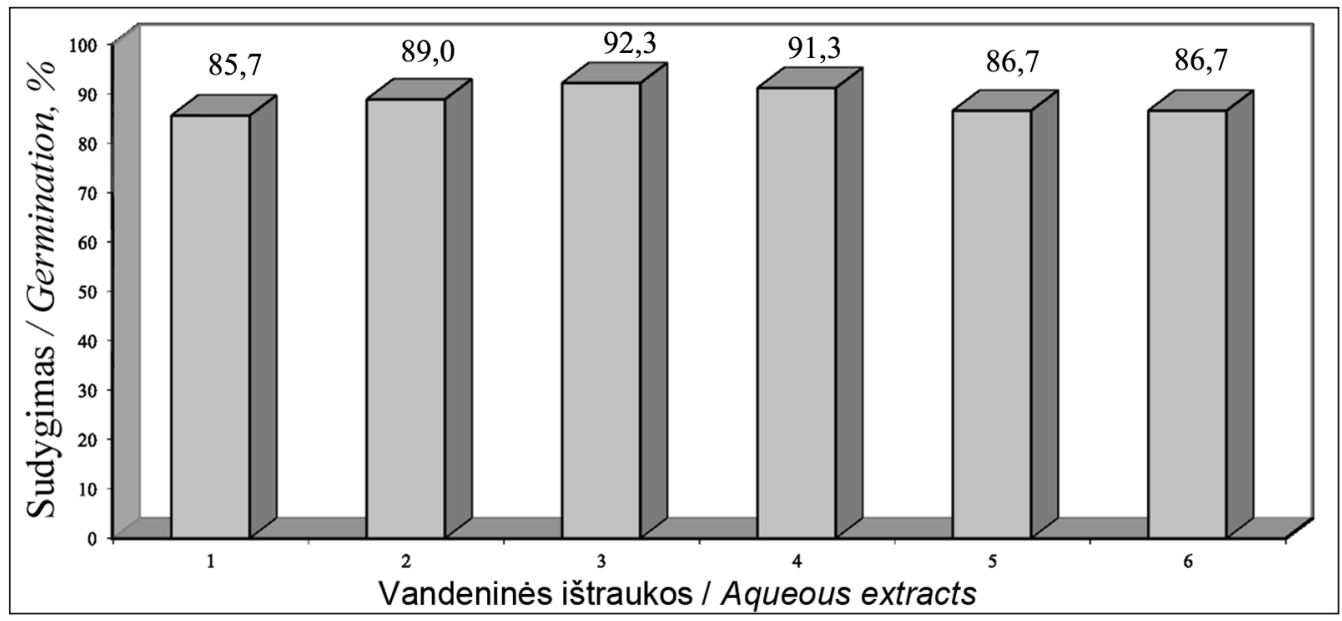

2 pav. Paprastojo kiečio biomasès vandeninių ištraukų alelopatinè ịtaka žieminių kviečių sudygimui, $2011 \mathrm{~m}$.

Pastaba: vandeninès ištraukos: 1) distiliuotas vanduo; 2) 1:6250 (kiečio biomasès ir distiliuoto vandens santykis);3) $1: 1250$;4) $1: 250$;5) 1:50;6) $1: 10$. Esminių skirtumų nèra $(P>0,05)$.

Fig. 2. The allelopathic effect of different concentration aqueous extracts of common mugwort biomass on winter wheat germination, 2011

Note: concentrations of aqueous ectracts: 1) distilled water; 2) 1:6250 (ratio of common mugwort biomass and distilled water);3) $1: 1250$; 4) $1: 250$;5) $1: 50$;6) $1: 10$. Means are not significantly different $(P>0.05)$. 


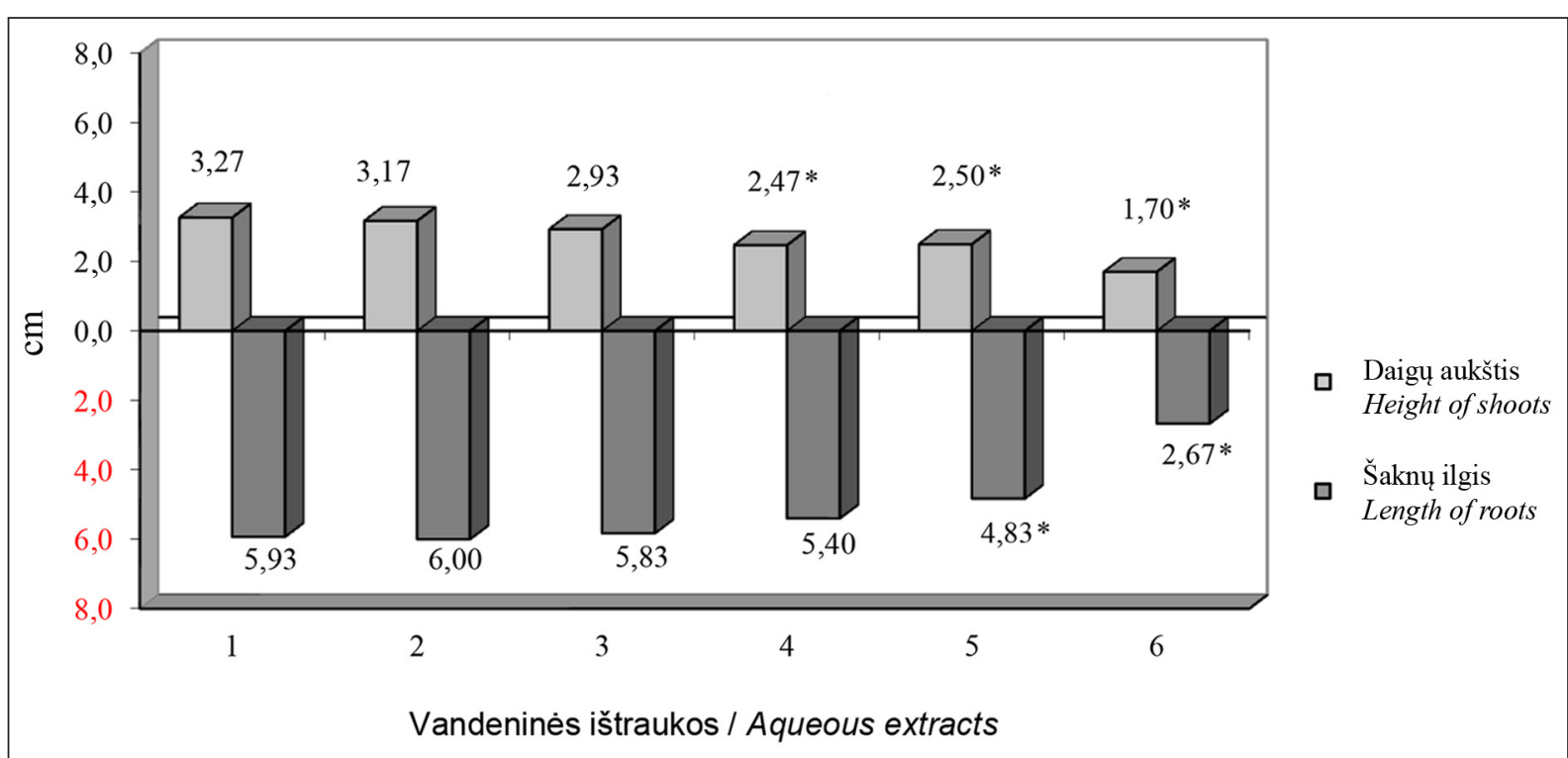

3 pav. Paprastojo kiečio biomasès vandeninių ištraukų alelopatinè įtaka žieminių kviečių daigų aukščiui ir šaknų ilgiui, $2011 \mathrm{~m}$.

Pastaba: vandeninès ištraukos: 1) distiliuotas vanduo; 2) 1:6 250 (kiečio biomasès ir distiliuoto vandens santykis); 3) $1: 1250$; 4) $1: 250$;5) $1: 50$;6) $1: 10 .{ }^{*}$ Esminiai $(\mathrm{P}<0,05)$ skirtumai, palyginti su distiliuotu vandeniu.

Fig. 3. The allelopathic effect of different concentration aqueous extracts of common mugwort biomass on height of winter wheat shoots and length of roots, 2011

Note: concentrations of aqueous ectracts: 1) distilled water; 2) 1:6250 (ratio of common mugwort biomass and distilled water); 3) $1: 1250$; 4) $1: 250$; 5) $1: 50$; 6) $1: 10 .{ }^{*}$ Significant $(P<0.05)$ difference compared with distilled water.

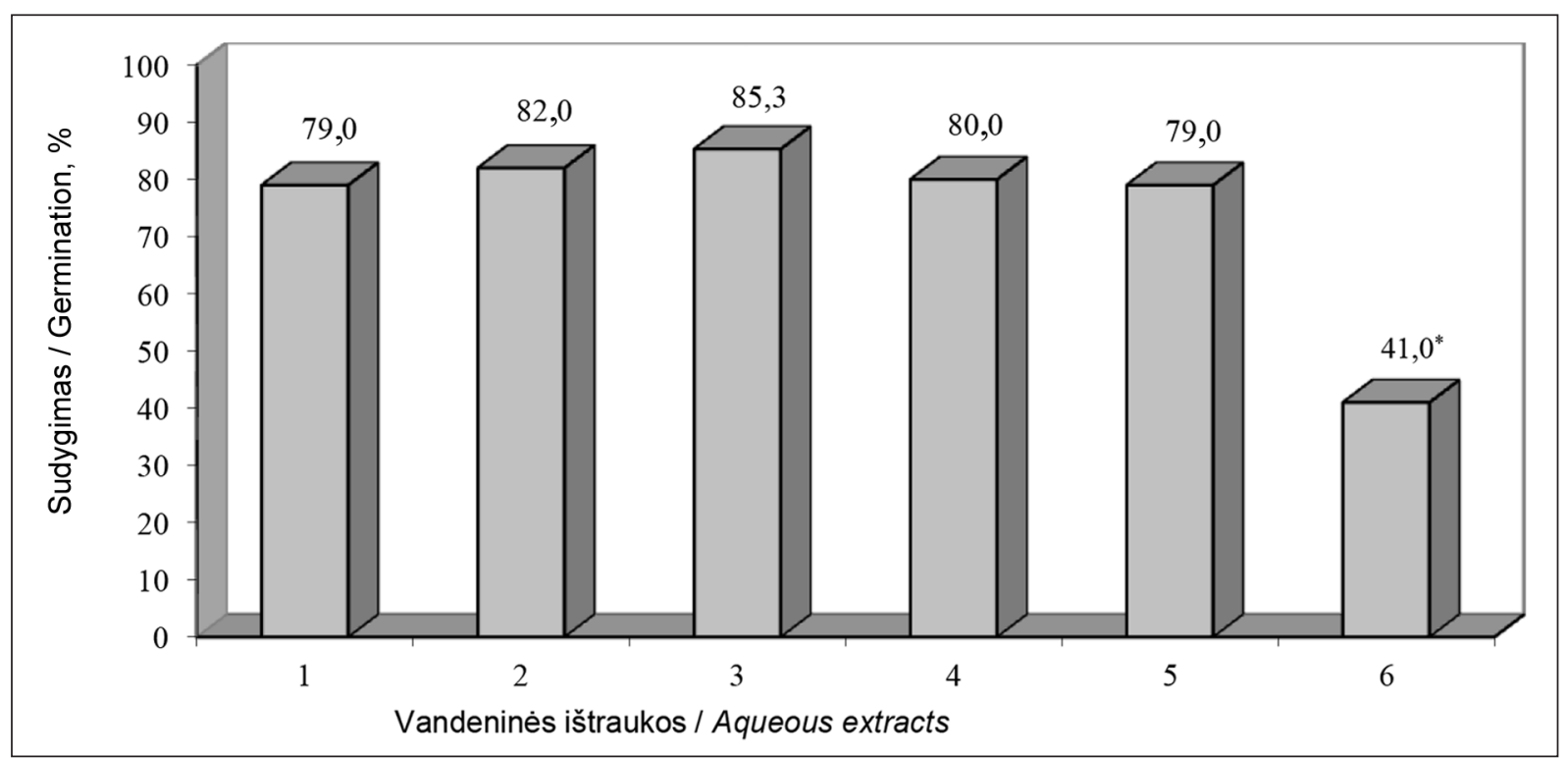

4 pav. Paprastojo kiečio biomasės vandeninių ištraukų alelopatinè įtaka vasarinių miežių sudygimui, $2011 \mathrm{~m}$. Pastaba: vandeninès ištraukos: 1) distiliuotas vanduo; 2) 1:6250 (kiečio biomasès ir distiliuoto vandens santykis); 3) $1: 1250$; 4) $1: 250$;5) $1: 50$; 6) $1: 10$. ${ }^{*}$ Esminiai $(\mathrm{P}<0$,05) skirtumai, palyginti su distiliuotu vandeniu.

Fig. 4. The allelopathic effect of different concentration aqueous extracts of common mugwort biomass on spring barley germination, 2011

Note: concentrations of aqueous ectracts: 1) distilled water; 2) 1:6250 (ratio of common mugwort biomass and distilled water); 3) $1: 1250$; 4) $1: 250$; 5) $1: 50$; 6) $1: 10 .{ }^{*}$ Significant $(P<0.05)$ difference compared with distilled water. 
distiliuotu vandeniu, sudygo juos daiginant paprastojo kiečio biomasès 1 : 10 koncentracijos vandeninejje ištraukoje. Kitų koncentracijų vandeninèse ištraukose miežių sudygimas esmingai nesiskyrè nuo sudygimo distiliuotame vandenyje.

Didžiausias vasarinių miežių daigų aukštis nustatytas juos daiginant distiliuotame vandenyje (5 pav.). Paprastojo kiečio biomasès silpesnių koncentracijų (1:6250, $1: 1250$ ir $1: 250)$ vandeninèse ištraukose, palyginti su distiliuotu vandeniu, miežių daigų aukštis esmingai nesiskyrè, o stipresnių koncentracijų (1:50 ir $1: 10)$ vandeninèse ištraukose miežių daigų aukštis esmingai sumažèjo nuo 12,2 iki 43,9 \%.

Vasarinių miežių šaknų augimas, palyginti su distiliuotu vandeniu, esmingai buvo slopinamas $(48,8 \%)$ tik stipriausios koncentracijos (1: 10) vandeninèje ištraukoje. Kitų koncentracijų vandeninèse ištraukose daigintų miežių šaknų ilgis esmingai nesiskyrè nuo šaknų ilgio distiliuotame vandenyje.

\section{IŠVADOS}

1. Didžiausias bendras fenolinių junginių kiekis nustatytas paprastojo kiečio lapuose. Kiečio žiedynuose, stiebuose ir šaknyse, palyginti su lapais, fenolinių junginių kaupèsi esmingai mažiau - nuo 19,7 iki $54,4 \%$.

2. Paprastojo kiečio biomasès skirtingų koncentracijų vandeninès ištraukos, palyginti su distiliuotu vandeniu, žieminių kviečių sudygimui esminès įtakos neturejjo, o vasarinių miežių dygimą esmingai slopino $48,1 \%$ stipriausios koncentracijos (1:10) vandeninè ištrauka.

3. Žieminių kviečių daigų (nuo 23,5 iki 48,0 \%) ir šaknų (nuo 18,5 iki 55,0 \%) augimas, palyginti su distiliuotu vandeniu, buvo slopinamas veikiant paprastojo kiečio $1: 250,1: 50$ ir $1: 10$ koncentracijų vandeninèmis ištraukomis, o miežių daigų (nuo 12,2 iki 43,9 \%) ir šaknų (48,8 \%) augimas - veikiant $1: 50$ ir $1: 10$ koncentracijų vandeninemis ištraukomis.

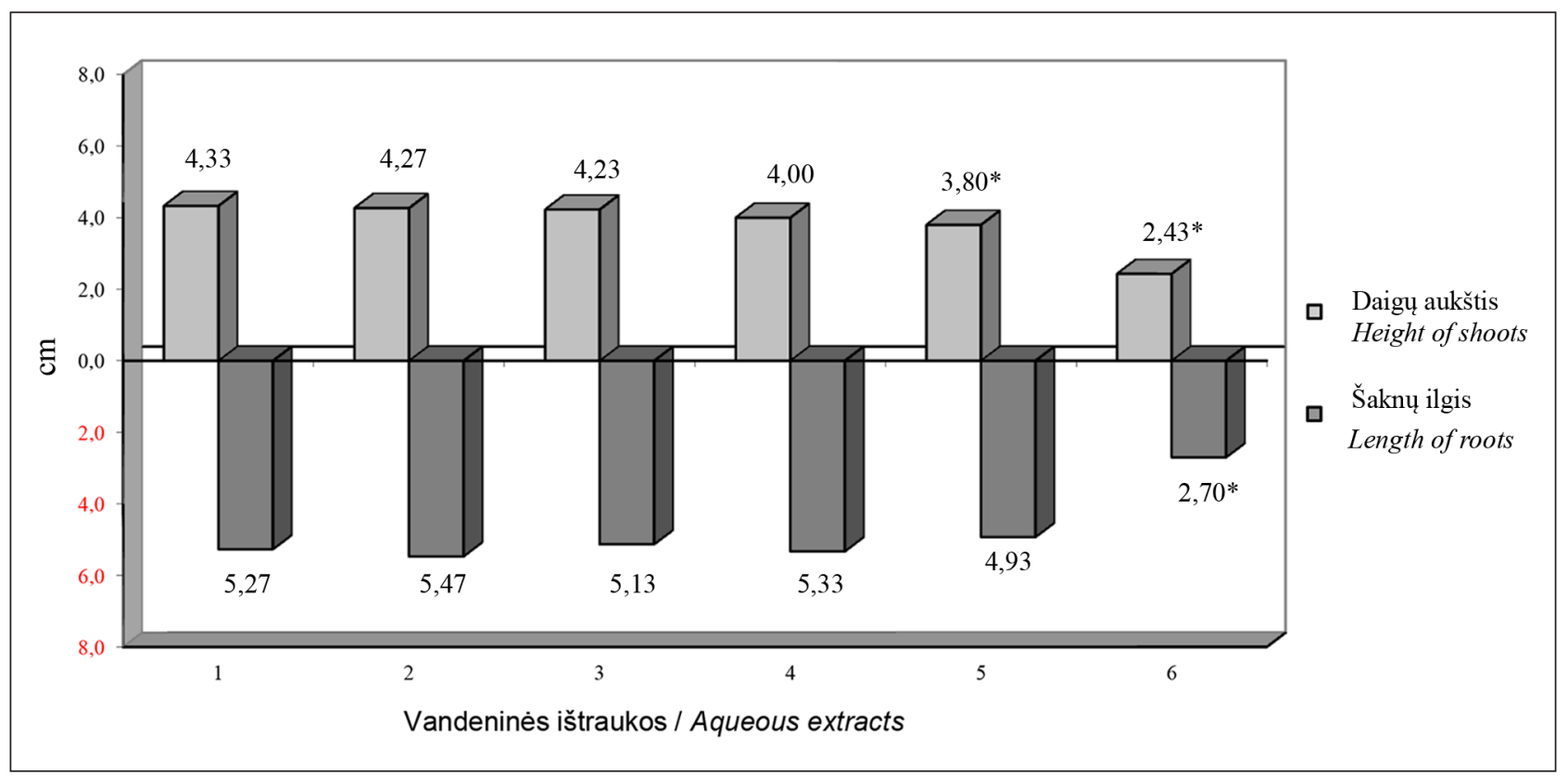

5 pav. Paprastojo kiečio biomasès vandeninių ištraukų alelopatinė ịtaka vasarinių miežių daigų aukščiui ir šaknų ilgiui, $2011 \mathrm{~m}$.

Pastaba: vandeninès ištraukos: 1) distiliuotas vanduo; 2) 1:6250 (kiečio biomasès ir distiliuoto vandens santykis); 3) 1:1250; 4) $1: 250$; 5) $1: 50$; 6$) 1: 10{ }^{*}$ Esminiai $(\mathrm{P}<0,05)$ skirtumai, palyginti su distiliuotu vandeniu.

Fig. 5. The allelopathic effect of different concentration aqueous extracts of common mugwort biomass on height of spring barley shoots and length of roots, 2011

Note: concentrations of aqueous ectracts: 1) distilled water; 2) $1: 6250$ (ratio of common mugwort biomass and distilled water);3) $1: 1250$;4) $1: 250$; 5) $1: 50$; 6) 1:10. " Significant $(P<0.05)$ difference compared with distilled water. 


\section{LITERATŪRA}

1. Abdel-Fattah R. I., Abou-Zeid A. M., Altalhi A. D. 2011. Allelopathic effects of Artemisia princeps and Launae sonchoids on rhizospheric fungi and wheat growth. African Journal of Microbiology Research. Vol. 5. No. 4. P. 419-424.

2. Al-Watban A., Salama H. M. H. 2012. Physiological effects of allelopathic activity of Artemisia monosperma on common bean (Phaseolus vulgaris L.). International Research Journal of Plant Science. Vol. 3. No. 8. P. 158-163.

3. Auškalnienė O. 2006. Piktžolių konkurencijos kritinis periodas kukurūzų ir vasarinių miežių agrocenozèse. Vagos. Vol. 71. Nr. 2. P. 2-7.

4. Baleliūnas P. 1999. Kenksmingos piktžolès. Kaunas. P. 23-24.

5. Barney J. N., DiTommaso A. 2003. The biology of Canadian weeds. 118. Artemisia vulgaris L. Canadian Journal of Plant Science. Vol. 83. P. 205215.

6. Barney J. N., Hay A. G., Weston L. A. 2005. Isolation and characterization of allelopathic volatiles from mugwort (Artemisia vulgaris L.). Journal of Chemical Ecology. Vol. 31. No. 2. P. 247-263.

7. Čiuberkis S., Vilkonis K. K. 2013. Piktžoles Lietuvos agroekosistemos: monografija. LAMMC, Šiaulių universitetas. P. 126-222.

8. Delabays N., Slacanin I., Bohren D. 2008. Herbicidal potential of artemisinin and allelopathic properties Artemisia annua L.: from the laboratory to the field. Journal of Plant Diseases and Protection. Special Issue XXI. P. 317-322.

9. Gill L. S., Anoliefo G. O., Iduoze U. V. 2009. Allelopathic Effects of Aqueous Extract from Siam Weed on the Growth of Cowpea. Nigeria: University of Benin. P. 3-20.

10. Grodzinskiy A. M. 1965. Allelopatiya v zhizni rasteniy i ikh soobshchestv. Kiev. S. 3-198.

11. Holm L., Doll J., Holm E., Pancho J., Herberger J. 1997. Journal of World Weeds: Natural Histories and Distribution. New York. 1129 p.

12. Korsmo E., Vidme T., Fykse H. 1981. Korsmos Ugrasplansjer. Oslo. 295 p.

13. Lazauskas P. 1990. Agrotechnika prieš piktžoles. Vilnius: Mokslas. 292 p.
14. Li M., Gao X. H., Gao Z. J., Wang Q. 2010. Primary study on allelopathy of Artemisia vulgaris. Acta Prataculturae Sinica. Vol. 19. No. 6. P. 114-119.

15. Lietuvos dirvožemiai: monografija. 2001. Vilnius: LMA. $1244 \mathrm{p}$.

16. Melkania N. P., Singh J. S., Bisht K. K. S. 1982. Allelopathic potential of Artemisia vulgaris L. and Pinus roxburghii sargent: bioassay study. Proceedings of the Indian Science Academy. Part B: Biological Sciences. No. 5. P. 685-688.

17. Önen H., Özer Z. 1999. The effects of dried mugwort (Artemisia vulgaris L.) leaves and rhizomes on germination and seedling growth of some crop species. Turkiye Herboloji Dergisi. Vol. 2. No. 2. 22-30.

18. Pannacci E., Pettorossi D., Regni L., Tei F. 2011. Allelopathic effects of Artemisia vulgaris L. (mugwort) on seed germination and growth of Sinapis alba L., Triticum aestivum L. and Lolium multiflorum Lam. 1 p. [cited 2012-04-03]. Available from: http://huesca.ewrs.org/doc/abstracts/41\%20 Euro_Pannacci_etal\%20REV\%20BR.doc/

19. Ragaee S., El-Sayed M. A. A., Noaman M. 2006. Antioxidant activity and nutrient composition of selected cereals for food use. Food Chemistry. Vol. 98. P. 32-38.

20. Rašomavičius V. 2008. Laukų augalijos tyrimai: mokslinè ataskaita. Vilnius. $74 \mathrm{p}$.

21. Raudonius S., Jodaugienė D., Pupalienè R., Trečiokas K. 2009. Moksliniu tyrimu metodika. Akademija, Kauno r. 119 p.

22. Špokienè N., Povilionienè E. 2003. Piktžolès. Akademija, Kauno r. 200 p.

23. Uludag A., Uremis I., Arslan M., Gozcu D. 2006. Allelopathy studies in weed science in Turkey a review. Journal of Plant Diseases and Protection. Vol. 20. P. 419-426.

24. Weston L. A., Duke S. O. 2003. Weed and crop allelopathy. Critical Reviews in Plant Sciences. Vol. 22. Issues 3-4. P. 367-389.

25. Xuan T. D., Tawata S., Khanh T. D., Chung I. M. 2005. Decomposition of allelopathic plants in soil. Journal of Agronomy and Crop Science. Vol. 191. P. 162-171. 
Aušra Marcinkevičienè, Edita Eimutytė,

Gabrielè Antanavičienè

THE ALLELOPATHIC EFFECT OF COMMON

MUGWORT (ARTEMISIA VULGARIS L.) ON WINTER WHEAT AND SPRING BARLEY

Sum $m$ ary

The investigations were carried out at the Experimental Station of Aleksandras Stulginskis University in 2011 ant 2012. The objective of these investigations was to determine the allelopathic effect of common mugwort biomass on winter wheat and spring barley. The allelopathic influence of different concentration aqueous extracts of common mugwort biomass (aboveground part and roots) on winter wheat and spring barley grains germination and early growth was investigated in a climate chamber RUMED 1301 in Petri dishes on filter paper, moistened with the prepared water extracts. Treatments of the experiment: 1) distilled water (control); 2) $1: 6250$ (ratio of common mugwort biomass and distilled water); 3) $1: 1250$; 4) $1: 250$; 5) $1: 50$; 6) $1: 10$.

The highest total content of phenolic compounds was determined in the leaves of common mugwort. Flowers, stems and roots of mugwort, compared with leaves, accumulated phenolic compounds significantly less - from 19.7 to $54.4 \%$. Different concentration aqueous extracts of mugwort biomass, as compared to distilled water, had no significant effect on winter wheat germination. The highest concentration aqueous extract of mugwort biomass, compared with distilled water, significantly inhibited germination of spring barley - by $48.1 \%$. It has been established that the growth of winter wheat shoots (from 23.5 to $48.0 \%$ ) and roots (from 18.5 to $55.0 \%)$ was inhibited under the influence of $1: 250$, $1: 50$ and $1: 10$ concentrations of aqueous extracts of mugwort biomass. The growth of spring barley shoots (from 12.2 to $43.9 \%)$ and roots (48.8\%) was inhibited under the effect of $1: 50$ and $1: 10$ concentrations of aqueous extracts of mugwort biomass.

Key words: common mugwort, total content of phenolic compounds, allelopathic effect 